\title{
Effect of Different Roasting Temperatures on Acrylamide Formation of Some Different Nuts
}

\author{
Müesser Süvari ${ }^{1}$, Göksel Tırpancı Sivri ${ }^{1}$, Ömer Öksüz ${ }^{1}$ \\ ${ }^{1}$ (Department of Food Engineering, Graduate School of Natural and Applied Sciences, Namık Kemal \\ University, Turkey)
}

\begin{abstract}
Consumers may prefer double roasted nuts as snack food since roasting process result in formation of aromatic compounds, taste and development of color in nut products. However, applying of high temperatures (above $120^{\circ} \mathrm{C}$ ) to foods which include proteins and carbohydrates causes some toxic compounds such as acrylamide. In this study, acrylamide formation during roasting process was investigated at three different temperatures on almonds, sunflower seeds and peanuts that consumed in common. For that reason, total 12 samples which include raw samples of each nut were investigated. Acrylamide contents of all samples were determined by UHPLC-MS/MS. The method's limit of detection (LOD) and limit of quantification (LOQ)

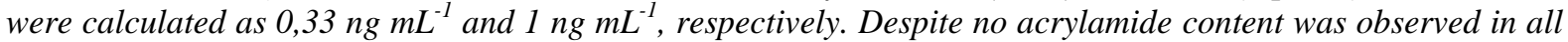
unroasted nuts, increasing of temperature degrees promoted the occurrence of acrylamide. The highest concentration of acrylamide was determined in almonds (273 $\left.\mathrm{ng} \mathrm{mL}^{-1}\right)$, the lowest in peanuts $\left(60.5 \mathrm{ng} \mathrm{mL^{-1 }}\right)$ under different roasting conditions.
\end{abstract}

Keywords: Acrylamide, Almonds, Peanuts, Sunflower seeds, UHPLC-MS/MS

\section{Introduction}

Heat treatments including cooking, frying, grilling, roasting and sterilization, usually applied at 90 $220^{\circ} \mathrm{C}$ for food production and preservation. Heat treatment at high temperatures may result in formation of some toxic compounds, which can decrease the nutrition value and put food safety in danger. Those compounds are heterocyclic amines, polycyclic aromatic hydrocarbons, N-alkyl-N-nitrozamines and acrylamide which are known as carcinogenic and mutagenic components ${ }^{[1,2]}$. Acrylamide has been specified as 'likely carcinogen for humans' and included in Group 2A by the International Agency for Research on Cancer ${ }^{[3]}$.

Acrylamide which forms because of heat treatment on high temperatures $\left(120^{\circ} \mathrm{C}\right)$ of food containing carbohydrates and protein, is not a compound naturally found in foods ${ }^{[4]}$. There are many studies indicating that acrylamide forms in many foods such as potato chips, French fries, bread, biscuits, cakes, cereals, coffee, cocoa, roasted nuts and cornflakes, because of production conditions ${ }^{[5,6,7,8]}$. There are many major and minor pathways causing acrylamide formation. Acrylamide is generally formed in parallel to the Maillard reaction from the free amino acid asparagine and reducing sugars [9]. Addition to Maillard reaction, it is reported that 3aminopropionamide compound, decarboxylated Amadori product, acrylic acid and acrolein forms acrylamide with different mechanisms ${ }^{[2,10,11,12,13]}$. Nuts as snack food are processed with heat treatments at different temperatures before going to market both in Turkey and in the World. Roasting process result in removal of raw taste and decreasing water activity which bring long shelf together.

Some consumers may demand or prefer double roasted nut products because of taste which is enhanced by aromatic compounds forming during roasting process. Regarding the consumer preferences, food producers put double roasted products on market. Double roasted products are prepared by setting either higher temperature or longer time parameters. The aim of this study was to investigate the effect of heat treatment at different temperatures on snacks including sunflower seeds, almonds and peanuts which are consumed commonly in Turkey. In this content, raw sunflower seeds, almonds and peanuts were roasted at three different temperatures under laboratory conditions and then, the dry matter, $\mathrm{pH}$, ash, protein and fat contents, color change, sensory evaluation were performed. The results were evaluated statistically to determine the correlations between acrylamide formation and other parameters.

\section{Materials and Method}

There were 12 nut samples which were raw and roasted at 3 different temperatures from each kind of nuts including sunflower seed, almond and peanuts. Raw samples were packaged under controlled atmosphere and kept at laboratory conditions. All chemicals including acetonitrile (Panreac, Barcelona-Spain), anhydrous $\mathrm{MgSO}_{4}$, acrylamide standard, formic acid (Sigma Aldrich-UK), and n-hexane, $\mathrm{NaCl}, \mathrm{Al}_{2} \mathrm{O}_{3}$ (Merck-Darmstadt, Germany) were analytical grade. Dry matter, ash and protein contents, $\mathrm{pH}$, color $\left(\mathrm{L}^{*}, \mathrm{a}^{*}, \mathrm{~b}^{*}\right)$ values of all samples were analyzed. Optimum roasting time and temperature parameters were determined with preliminary test. Tested time-temperature combinations were decided based upon the commercial applications. In order to 
evaluate the temperature effect, it was gradually increased for every nut type's time was constant for each process. Analysis of acrylamide formation and other parameters were repeated 3 times with 2 parallels. In Table 1 , roasting time and temperature parameters of each kind of nuts are shown.

Table 1 Roasting process parameters (time-temperature)

\begin{tabular}{|l|c|c|c|c|}
\hline \multicolumn{1}{|c|}{ Type of nuts } & $\begin{array}{c}\text { Roasting Time } \\
(\mathbf{m i n})\end{array}$ & $\begin{array}{c}\text { 1. roasting } \\
\text { temperature }\left({ }^{\circ} \mathbf{C}\right)\end{array}$ & $\begin{array}{c}\text { 2. roasting } \\
\text { temperature }\left({ }^{\circ} \mathbf{C}\right)\end{array}$ & $\begin{array}{c}\text { 3. roasting } \\
\text { temperature }\left({ }^{\circ} \mathbf{C}\right)\end{array}$ \\
\hline Sunflower seeds with shell & 23 & 160 & 165 & 170 \\
\hline Almonds & 23 & 140 & 145 & 150 \\
\hline Peanuts & 40 & 150 & 155 & 160 \\
\hline
\end{tabular}

\subsection{Sample preparation procedure for acrylamide analysis}

The sample preparation procedure for acrylamide analysis was performed according to Ali Omar et al. with some minor modifications ${ }^{[14]}$. Homogenized 1 gram of nut sample was put into $50 \mathrm{~mL}$ centrifuge tube. 5 $\mathrm{mL} \mathrm{n}$-hexane is added to the tubes for separating fat part and then it was shaken for 1 minute. Afterwards $10 \mathrm{~mL}$ of ultrapure water, $10 \mathrm{~mL}$ of acetonitrile, $5 \mathrm{~g}$ of anhydrous $\mathrm{MgSO}_{4}$ and $1 \mathrm{~g}$ of $\mathrm{NaCl}$ mixture were added into the tubes. Samples were immediately mixed for 1 minute to avoid crystallization after addition of salt mixture. All samples were centrifuged at $4500 \mathrm{rpm}$ for 6 minutes. After that 4 separate layers were observed. The top layer of hexane is removed. $3 \mathrm{~mL}$ of acetonitrile layer which contains acrylamide was transferred into $10 \mathrm{~mL}$ of small centrifuge tubes which contained $150 \mathrm{mg}$ aluminium oxide. Later the samples including acrylamide were vortexed for 30 seconds and centrifuged at $4500 \mathrm{rpm}$ for 3 minutes. $1 \mathrm{~mL}$ of supernatant was taken with injector and filtered through $0,45 \mu \mathrm{m}$ Nacherey-Nagel filter, then transferred into glass tubes to evaporate under light stream of nitrogen gas. Dried residues were diluted with $200 \mu \mathrm{L}$ ultrapure water and then vortexed for 1 minute. The samples were transferred into mini centrifuge vials and centrifuged at $10.000 \mathrm{rpm}$ for 8 minutes. After this stage the supernatant was injected into a UHPLC auto sampler vial. Quantative analysis of acrylamide formation were determined at $\mathrm{ng} \mathrm{mL}^{-1}$ level by using Ultra High Pressure Liquid Chromotography Mass Specthrometry (UHPLC-MS/MS).

\subsection{Calibration curve preparation for acrylamide analysis}

To prepare calibration curve, standart solutions at 7 different concentaration (ranged 0.1-100.0 ppb) were prepared. The linearity of calibration curve was shown in Fig. 1. $(\mathrm{R}=0,9998)$. The seperation of acrylamide was done at UHPLC AB Sciex 3200 QTrap LC-MS/MS. Venusil AQ $3 \mu \mathrm{m}$ C18 $100 \AA$ (2,1*50 mm) colon was used as chromatographic colon. Mobile phase A (\% 90) was \% 0,1 formic acid in ultrapure water and mobile phase B (\%10) was \% 0,1 formic acid in acetonitrile at flow rate $0,4 \mathrm{~mL} \mathrm{~min}^{-1}$. Aliquots of $20 \mu \mathrm{L}$ of the sample extract were injected into the chromatographic system using the autosampler. The ionization type was turbo ion spray positive polarity. Temperatures were $40^{\circ} \mathrm{C}$ and $550^{\circ} \mathrm{C}$ oven and gas, respectively. Capillary voltage was $5000 \mathrm{~V}$ and press of nebulizer 1:2 were 40:60 psi.

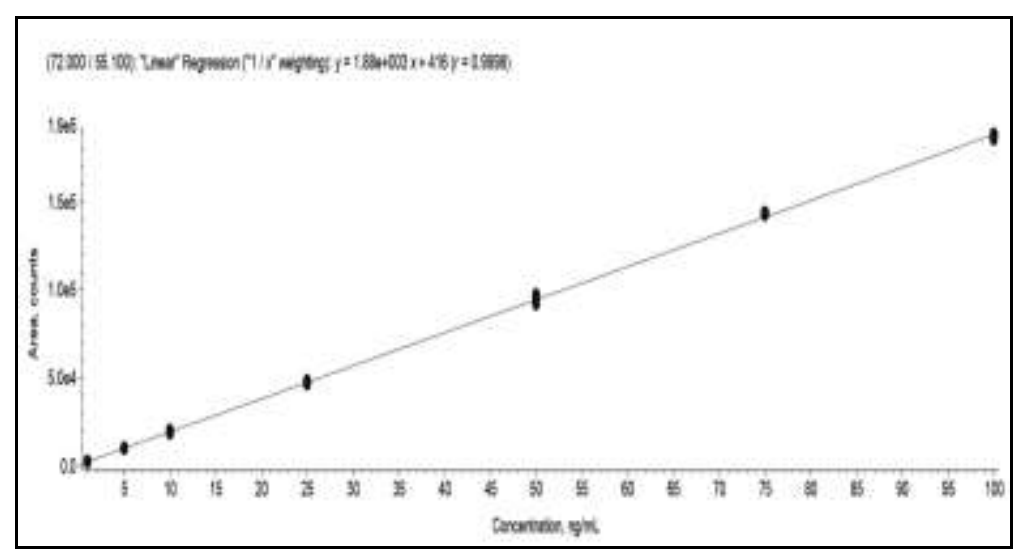

Figure 1. Calibration curve of acrylamide standarts $(0.1,5.0,10.0,25.0,50.0,75.0$ and $100.0 \mathrm{ppb})$

\subsection{Determination of recovery values, LOD and LOQ for acrylamide analysis}

For recovery study, unroasted nut samples including sunflower seeds, almonds and peanuts were used. After fat seperation of samples, they were spiked with acrylamide standards at different concentrations. Extraction of acrylamide was performed as explained before. The extract which was obtained from this process was diluted by mobile phase and calibration curve points were prepared. LOD and LOQ values were calculated with these equilibrium:

$$
\mathrm{LOD}=3,3 * \mathrm{~s} / \mathrm{S} \text { and } \mathrm{LOQ}=10 * \mathrm{~s} / \mathrm{S}^{[14]} \text {. }
$$


In specific concentration; s indicates the lowest concentration and $\mathrm{S}$ shows the signal/noise rate in the lowest concentration. According to these equilibrium the sample's limit of detection (LOD) and limit of quantification (LOQ) values were determined as $0,33 \mathrm{ng} \mathrm{mL}^{-1}$ and $1 \mathrm{ng} \mathrm{mL}^{-1}$ respectively.

\section{Result and Discussion}

\subsection{The physicochemical properties and acrylamide content of sunflower seed roasted at different} temperatures

The physicochemical properties which are dry matter, ash, protein and fat content, $\mathrm{pH}$ and color parameter of sunflower seed are indicated in Table 2 . As seen in Table 2, \% dry matter, $\%$ ash, $\%$ protein and $\%$ fat content and $a^{*}$ value were increased with rising temperature. The differences of each samples were statistically significant $(\mathrm{p}<0,05)$. The difference of between $\mathrm{pH}$ values of raw samples and samples roasted at $170^{\circ} \mathrm{C}$ were not important $(\mathrm{p}>0,05)$ statistically, whereas others were confirmed as significantly different $(\mathrm{p}<0,05)$. While the roasting temperature increased, the $\mathrm{L}^{*}$ value of samples initially rose and then decreased. Rising temperaure caused to increase $\mathrm{a}^{*}$ value of sunflower seeds. In a different study, Özdemir et. al. reported the highest $\mathrm{a}^{*}$ value $(4,07)$ of hazelnuts in the minimum water activity ${ }^{[15]}$. All the $\mathrm{b}^{*}$ value of the samples increased gradually while temperature increasing, it decreased slightly at highest roasting temperature $\left(170^{\circ} \mathrm{C}\right)$. The differences between $b *$ values of each sunflower seed samples were significantly important $(p<0,05)$.

Table 2 Dry matter, ash, protein and fat content, $\mathrm{pH}$ and color parameter of sunflower seed roasted at 160, 165 and $170^{\circ} \mathrm{C}$ for 23 minutes $(\mathrm{n}=6)$

\begin{tabular}{|c|c|c|c|c|c|c|c|c|}
\hline & & ANAL & $\begin{array}{l}\text { ES AND } \\
\text { (AV }\end{array}$ & $\begin{array}{l}\text { SULTS OF } \\
\text { AGE RATIC }\end{array}$ & FLOW & EEDS & & \\
\hline ROASTING & DRY & & & & & & COLO & \\
\hline $\begin{array}{c}\text { TEMPERATURE } \\
\left({ }^{\circ} \mathrm{C}\right)\end{array}$ & $\begin{array}{c}\text { MATTER } \\
(\%)\end{array}$ & $\begin{array}{c}\text { ASH } \\
(\%)\end{array}$ & pH & $\begin{array}{c}\text { PROTEIN } \\
(\%)\end{array}$ & $\begin{array}{c}\text { FAT } \\
(\%)\end{array}$ & $\mathbf{L}^{*}$ & $\mathbf{a}^{*}$ & $\mathbf{b}^{*}$ \\
\hline $\begin{array}{l}\text { Unroasted } \\
\text { sample }\end{array}$ & $\begin{array}{c}95,17 \\
\pm 0,18^{\mathrm{a}}\end{array}$ & $\begin{array}{l}3,4991 \\
\pm 0,29^{\mathrm{a}}\end{array}$ & $\begin{array}{c}6,08 \\
\pm 0,27^{\mathrm{c}}\end{array}$ & $\begin{array}{l}10,961 \\
\pm 0,31^{\text {a }}\end{array}$ & $\begin{array}{l}40,673 \\
\pm 0,55^{\text {a }}\end{array}$ & $\begin{array}{l}52,28 \\
\pm 0,04^{\mathrm{a}}\end{array}$ & $\begin{array}{c}-0,22 \\
\pm 0,14^{\mathrm{a}}\end{array}$ & $\begin{array}{c}9,57 \\
\pm 0,08^{\mathrm{a}}\end{array}$ \\
\hline 160 & $\begin{array}{r}98,40 \\
\pm 0,35^{\mathrm{b}}\end{array}$ & $\begin{array}{l}3,5860 \\
\pm 0,42^{b}\end{array}$ & $\begin{array}{c}5,67 \\
\pm 0,21^{\mathrm{b}}\end{array}$ & $\begin{array}{l}20,66 \\
\pm 0,01^{\mathrm{b}}\end{array}$ & $\begin{array}{l}44,227 \\
\pm 0,34^{\mathrm{b}}\end{array}$ & $\begin{array}{l}58,42 \\
\pm 0,15^{\text {d }}\end{array}$ & $\begin{array}{c}1,04 \\
\pm 0,08^{\mathrm{b}}\end{array}$ & $\begin{array}{r}15,07 \\
\pm 0,02^{\mathrm{b}}\end{array}$ \\
\hline 165 & $\begin{array}{r}98,67 \\
\pm 0,39^{c}\end{array}$ & $\begin{array}{l}3,6360 \\
\pm 0,31^{\mathrm{c}}\end{array}$ & $\begin{array}{c}5,56 \\
\pm 0,36^{\mathrm{a}}\end{array}$ & $\begin{array}{l}21,942 \\
\pm 0,28^{\mathrm{c}}\end{array}$ & $\begin{array}{l}48,334 \\
\pm 0,42^{\mathrm{c}}\end{array}$ & $\begin{array}{l}57,78 \\
\pm 0,13^{\mathrm{c}}\end{array}$ & $\begin{array}{c}2,14 \\
\pm 0,20^{\mathrm{c}}\end{array}$ & $\begin{array}{l}15,35 \\
\pm 0,20^{\mathrm{d}}\end{array}$ \\
\hline 170 & $\begin{array}{r}99,32 \\
\pm 0,34^{\text {d }} \\
\end{array}$ & $\begin{array}{l}3,7391 \\
\pm 0,25^{\mathrm{d}} \\
\end{array}$ & $\begin{array}{c}6,05 \\
\pm 0,35^{\mathrm{c}} \\
\end{array}$ & $\begin{array}{c}22,5581 \\
\pm 0,25^{\mathrm{d}}\end{array}$ & $\begin{array}{l}48,527 \\
\pm 0,39^{d} \\
\end{array}$ & $\begin{array}{r}54,00 \\
\pm 0,14^{\mathrm{b}} \\
\end{array}$ & $\begin{array}{c}3,17 \\
\pm 0,19^{d} \\
\end{array}$ & $\begin{array}{r}15,24 \\
\pm 0,13^{\mathrm{c}} \\
\end{array}$ \\
\hline
\end{tabular}

a-d: The values with same letter are not significantly different for each parameters $(\mathrm{p}>0.05)$

In acrylamide analysis, recovery value of sunflower seeds was calculated as \% 112,6. Acrylamide concentration showed positive correlation with increasing roasting temperature in sunflower seeds and the highest amount of acrylamide $\left(61,5 \mathrm{ng} \mathrm{mL}^{-1}\right)$ detected at the highest $\left(170^{\circ} \mathrm{C}\right)$ roasting temperature $(\mathrm{p}<0,01$, $\mathrm{R}=0,970)$. Comparably to our study, Jägerstad and Skog reported the concentration of acrylamide as $66 \mu \mathrm{g} \mathrm{kg}^{-1}$ in sunflower seeds ${ }^{[16]}$. Additionally, lower acrylamide contents were observed in sunflower seeds when compared with almonds and peanuts even though it roasted at $170^{\circ} \mathrm{C}$ which is higher than roasting temperature of other samples. Since sunflower seeds roasted with shell, it is thought that acrylamide formation may be prevented by shell providing protection effect from roasting process. However there is no enough research about the acrylamide content of sunflower seeds. The acrylamide concentrations of sunflower seeds with rising temperature is shown in Fig. 2.

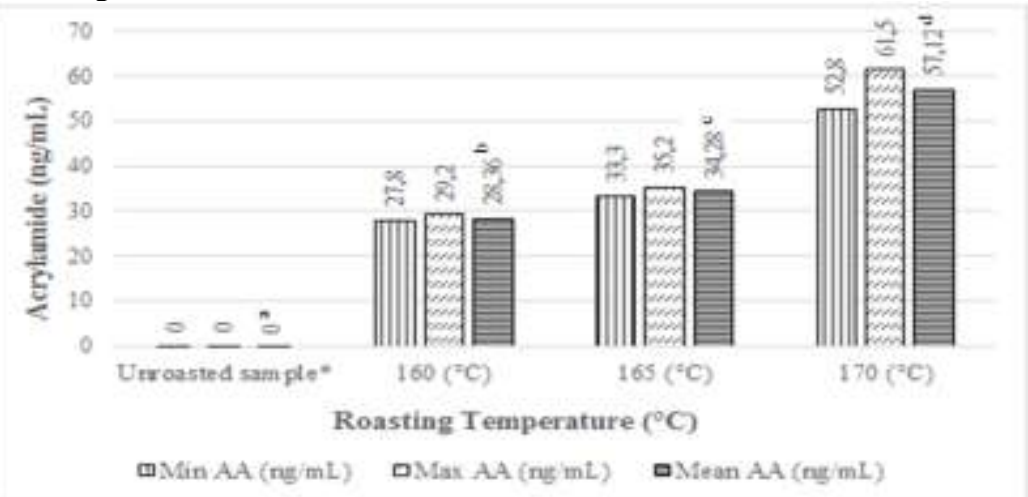

Figure 2 The minimum (Min), maximum (Max) and average (Mean) acrylamide (AA) concentrations of sunflower seeds roasted at different temperatures $(n=6)$

*Under the detection limit (LOD $=0,33 \mathrm{ng} \mathrm{mL}^{-1}$ )

a-d: The values with same letter are not significantly different for each parameters $(p>0.05)$ 


\subsection{The physicochemical properties and acrylamide content of almond roasted at different temperatures}

Investigated properties of almond including $\%$ dry matter, $\%$ ash, $\%$ protein, $\%$ fat and $a^{*}$ value increased with rising temperature. Contrary to this situation, rising temperature caused a decrease in $\mathrm{pH}, \mathrm{L}^{*}$ and $\mathrm{b}^{*}$ values of the samples. Also, it was found that the physicochemical properties of all samples processed at different temperatures were significantly different $(p<0,05)$. The physicochemical properties which are dry matter, ash, protein and fat content, $\mathrm{pH}$ and color parameter of almonds are indicated in Table 3.

Table 3 Dry matter, ash, protein and fat content, $\mathrm{pH}$ and color parameter of almond roasted at 140, 145 and $150^{\circ} \mathrm{C}$ for 23 minutes $(\mathrm{n}=6)$

\begin{tabular}{|c|c|c|c|c|c|c|c|c|}
\hline \multicolumn{9}{|c|}{$\begin{array}{l}\text { THE ANALYSES AND RESULTS OF ALMONDS } \\
\text { (AVERAGE RATIOS) }\end{array}$} \\
\hline \multirow{2}{*}{$\begin{array}{c}\text { ROASTING } \\
\text { TEMPERATURE } \\
\left({ }^{\circ} \mathrm{C}\right)\end{array}$} & \multirow{2}{*}{$\begin{array}{c}\text { DRY } \\
\text { MATTER } \\
(\%)\end{array}$} & \multirow{2}{*}{$\begin{array}{c}\text { ASH } \\
(\%)\end{array}$} & \multirow{2}{*}{ pH } & \multirow{2}{*}{$\begin{array}{c}\text { PROTEIN } \\
(\%)\end{array}$} & \multirow{2}{*}{ FAT $(\%)$} & \multicolumn{3}{|c|}{ COLOR } \\
\hline & & & & & & $\mathbf{L} *$ & $a^{*}$ & $\mathbf{b}^{*}$ \\
\hline $\begin{array}{l}\text { Unroasted } \\
\text { sample }\end{array}$ & $\begin{array}{l}96,00 \\
\pm 0,28^{\mathrm{a}}\end{array}$ & $\begin{array}{l}2,9435 \\
\pm 0,25 \mathrm{a}\end{array}$ & $\begin{array}{c}6,148 \\
\pm 0,03 \mathrm{~d}\end{array}$ & $\begin{array}{l}19,945 \\
\pm 0,35^{\mathrm{a}}\end{array}$ & $\begin{array}{l}34,88 \\
\pm 0,02^{\mathrm{a}}\end{array}$ & $\begin{array}{l}37,728 \\
\pm 0,04^{\mathrm{d}}\end{array}$ & $\begin{array}{l}10,32 \\
\pm 0,09^{\mathrm{a}}\end{array}$ & $\begin{array}{l}16,393 \\
\pm 0,01^{\mathrm{d}}\end{array}$ \\
\hline 145 & $\begin{array}{l}97,77 \\
\pm 0,33^{\mathrm{c}}\end{array}$ & $\begin{array}{l}3,0397 \\
\pm 0,34^{\mathrm{c}}\end{array}$ & $\begin{array}{l}5,826 \\
\pm 0,03^{b}\end{array}$ & $\begin{array}{l}20,416 \\
\pm 0,27^{\mathrm{c}}\end{array}$ & $\begin{array}{l}43,98 \\
\pm 0,03^{\mathrm{c}}\end{array}$ & $\begin{array}{l}35,706 \\
\pm 0,01^{\mathrm{b}}\end{array}$ & $\begin{array}{l}11,166 \\
\pm 0,05^{\mathrm{c}}\end{array}$ & $\begin{array}{r}15,36 \\
\pm 0,02^{b}\end{array}$ \\
\hline 150 & $\begin{array}{c}98,21 \\
\pm 0,27^{\mathrm{d}} \\
\end{array}$ & $\begin{array}{l}3,0912 \\
\pm 0,12^{\mathrm{d}} \\
\end{array}$ & $\begin{array}{c}5,71 \\
\pm 0,03^{\mathrm{a}} \\
\end{array}$ & $\begin{array}{l}20,57 \\
\pm 0,33^{\text {d }} \\
\end{array}$ & $\begin{array}{c}45,02 \\
\pm 0,03^{\mathrm{d}} \\
\end{array}$ & $\begin{array}{l}35,593 \\
\pm 0,01^{\text {a }} \\
\end{array}$ & $\begin{array}{c}11,07 \\
\pm 0,08^{\text {b,c }} \\
\end{array}$ & $\begin{array}{c}15,033 \\
\pm 0,005^{\mathrm{a}} \\
\end{array}$ \\
\hline
\end{tabular}

The highest acrylamide concentration was determined as $273 \mathrm{ng} \mathrm{mL} \mathrm{m}^{-1}$ in almonds roasted at $150^{\circ} \mathrm{C}$ which was the highest temperature applied (Fig.3). A positive correlation was detected between acrylamide formation and increasing roasting temperature $(\mathrm{R}=0,905)$. In acrylamide analysis, recovery value of almond samples was calculated as \% 108,2. Similar roasting conditions were applied to almonds in the study of Lukac et. al. and the acrylamide contents were determined as an average $494 \mu \mathrm{g} \mathrm{kg}^{-1}$ [17]. Tekkeli et. al. reported that acrylamide content of almonds as $95,5 \mu \mathrm{g} \mathrm{kg}^{-1}$ after they applied stacking technique ${ }^{[18]}$. This differences may based on variety of almonds, and process conditions.

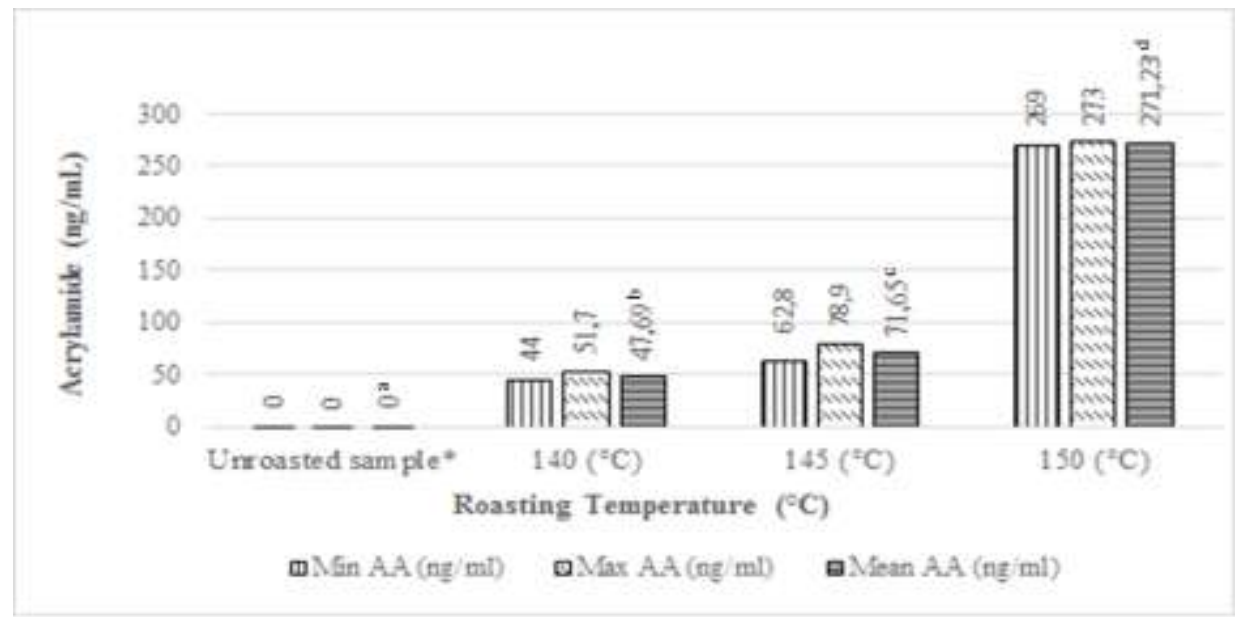

Figure 3. The minimum (Min), maximum (Max) and average (Mean) acrylamide (AA) concentrations of almonds roasted at different temperatures $(n=6)$

*Under the detection limit ( $\mathrm{LOD}=0,33 \mathrm{ng} \mathrm{mL}^{-1}$ )

a-d: The values with same letter are not significantly different for each parameters $(p>0.05)$

Friedman stated that the acrylamide concentration in almond samples was as $260 \mu \mathrm{g} \mathrm{kg}^{-1}$ in his review including various foods ${ }^{[19]}$. Similarly acrylamide content of almond ranged from $207-313 \mu \mathrm{g} \mathrm{kg}^{-1}$ (mean $260 \mu \mathrm{g}$ $\mathrm{kg}^{-1}$ ) in Ölmez et al. 's study ${ }^{[8]}$. There is a review about acrylamide content of the food products including almonds roasted with salt reported the concentration as average $657 \mu \mathrm{g} \mathrm{kg}^{-1}{ }^{[20]}$. In different almond products the acrylamide contents were determined by Amrein et. al. as follows: $443 \mu \mathrm{g} \mathrm{kg}^{-1}$ in roasted almonds, $196 \mu \mathrm{g} \mathrm{kg}^{-1}$ in bakery products containing almonds. According to Amrein et. al. the mean acrylamide concentration in all almond products was reported as $250 \mathrm{~g} \mathrm{~kg} \mathrm{k}^{-1}{ }^{[21]}$. As seen in the literature acrylamide contents are similar to result of this study. Heating process can cause increase in redness parameter of almond samples initially, however, $a^{*}$ value decreased subsequently after it reached the highest level. It also observed in this study $\mathrm{a}^{*}$ 
value of almond samples increased initially but it decreased at the highest roasting temperature $\left(150^{\circ} \mathrm{C}\right)$. Similarly, Gökmen and Şenyuva reported that a* value increased initially and than decreased in the highest roasting temperature in green coffee ${ }^{[22]}$.

\subsection{The physicochemical properties and acrylamide content of peanut roasted at three different temperatures}

The physicochemical properties including dry matter, ash, protein and fat content, $\mathrm{pH}$ and color parameters, of peanut are indicated in Table 4 . As a result of applying different roasting temperatures to peanut samples some changes were observed in nutrition values. While roasting temperature rising, $\%$ dry matter, $\%$ ash, $\%$ protein, $\%$ fat content, $\mathrm{a}^{*}$ and $\mathrm{b}^{*}$ values were increased. $\mathrm{pH}$ and $\mathrm{L}^{*}$ value decreased despite the high roasting temperatures. The differences between all peanut samples were determined significantly $(p<0,05)$.

Table 4 Dry matter, ash, protein and fat content, $\mathrm{pH}$ and color parameter of peanut roasted at 150, 155 and $160^{\circ} \mathrm{C}$ for 40 minutes $(\mathrm{n}=6)$

\begin{tabular}{|c|c|c|c|c|c|c|c|c|}
\hline \multicolumn{9}{|c|}{$\begin{array}{l}\text { THE ANALYSES AND RESULTS OF PEANUTS } \\
\text { (AVERAGE RATIOS) }\end{array}$} \\
\hline \multirow{2}{*}{$\begin{array}{c}\text { ROASTING } \\
\text { TEMPERATURE } \\
\left({ }^{\circ} \mathrm{C}\right)\end{array}$} & \multirow{2}{*}{$\begin{array}{c}\text { DRY } \\
\text { MATTER } \\
(\%)\end{array}$} & \multirow{2}{*}{$\begin{array}{c}\text { ASH } \\
(\%)\end{array}$} & \multirow{2}{*}{ pH } & \multirow{2}{*}{$\begin{array}{c}\text { PROTEIN } \\
(\%)\end{array}$} & \multirow{2}{*}{ FAT $(\%)$} & \multicolumn{3}{|c|}{ COLOR } \\
\hline & & & & & & $\mathbf{L}^{*}$ & $\mathbf{a}^{*}$ & $\mathbf{b}^{*}$ \\
\hline $\begin{array}{l}\text { Unroasted } \\
\text { sample }\end{array}$ & $\begin{array}{l}91,30 \\
\pm 0,02^{\mathrm{a}}\end{array}$ & $\begin{array}{l}2,0101 \\
\pm 0,38^{\mathrm{a}}\end{array}$ & $\begin{array}{c}6,5 \\
\pm 0,02 \mathrm{c}\end{array}$ & $\begin{array}{c}23,5073 \\
\pm 0,02^{\mathrm{a}}\end{array}$ & $\begin{array}{l}43,877 \\
\pm 0,02^{\mathrm{a}}\end{array}$ & $\begin{array}{l}62,251 \\
\pm 0,04^{\mathrm{d}}\end{array}$ & $\begin{array}{l}-0,151 \\
\pm 0,20^{\mathrm{a}}\end{array}$ & $\begin{array}{l}21,03 \\
\pm 0,03^{\mathrm{a}}\end{array}$ \\
\hline 150 & $\begin{array}{r}99,00 \\
\pm 0,03^{\text {b }}\end{array}$ & $\begin{array}{l}2,2260 \\
\pm 0,29^{\mathrm{b}}\end{array}$ & $\begin{array}{c}6,32 \\
\pm 0,03^{\mathrm{b}}\end{array}$ & $\begin{array}{l}24,879 \\
\pm 0,03^{\mathrm{b}}\end{array}$ & $\begin{array}{l}45,463 \\
\pm 0,02^{\mathrm{b}}\end{array}$ & $\begin{array}{l}54,766 \\
\pm 0,02^{\mathrm{c}}\end{array}$ & $\begin{array}{c}5,91 \\
\pm 0,11^{\text {b }}\end{array}$ & $\begin{array}{r}22,41 \\
\pm 0,04\end{array}$ \\
\hline 155 & $\begin{array}{r}99,14 \\
\pm 0,03^{\text {c }}\end{array}$ & $\begin{array}{l}2,2682 \\
\pm 0,03^{\mathrm{c}}\end{array}$ & $\begin{array}{c}6,26 \\
\pm 0,07^{\mathrm{b}}\end{array}$ & $\begin{array}{l}25,625 \\
\pm 0,02^{c}\end{array}$ & $\begin{array}{l}46,59 \\
\pm 0,03^{\mathrm{c}}\end{array}$ & $\begin{array}{l}54,078 \\
\pm 0,12^{\mathrm{b}}\end{array}$ & $\begin{array}{c}5,95 \\
\pm 0,05^{\mathrm{b}}\end{array}$ & $\begin{array}{r}22,19 \\
\pm 0,43^{\circ}\end{array}$ \\
\hline 160 & $\begin{array}{l}99,20 \\
\pm 0,02^{\mathrm{d}}\end{array}$ & $\begin{array}{l}2,3062 \\
\pm 0,03^{\mathrm{c}}\end{array}$ & $\begin{array}{c}6,19 \\
\pm 0,06^{\mathrm{a}}\end{array}$ & $\begin{array}{l}25,713 \\
\pm 0,02^{\mathrm{c}}\end{array}$ & $\begin{array}{l}47,433 \\
\pm 0,03^{\mathrm{d}}\end{array}$ & $\begin{array}{l}52,903 \\
\pm 0,11^{\text {a }}\end{array}$ & $\begin{array}{c}6,97 \\
\pm 0,12^{\mathrm{c}}\end{array}$ & $\begin{array}{r}22,03 \\
\pm 0,07^{\mathrm{b}}\end{array}$ \\
\hline
\end{tabular}

a-d: The values with same letter are not significantly different for each parameters $(p>0.05)$

In acrylamide analysis recovery value of peanuts was determined as $\% 105$. When the acrylamide contents of peanuts were investigated, the lowest $\left(21,4 \mathrm{ng} \mathrm{mL}^{-1}\right)$ and the highest $\left(60,5 \mathrm{ng} \mathrm{mL}^{-1}\right)$ concentrations were determined at $150^{\circ} \mathrm{C}$ and $160^{\circ} \mathrm{C}$ respectively as seen in Fig. 4 . The roasting temperature is the key factor for acrylamide formation in peanut samples, since there is a positive correlation between temperature and acrylamide concentration $(\mathrm{R}=0,934)$. A study conducted by Ölmez et. al. stated that acrylamide level of peanuts were determined as $66 \mu \mathrm{g} \mathrm{kg}^{-1}$, similarly to this study ${ }^{[8]}$. There is another study in New Zeland by Cressey et. al. to search the acrylamide content of various snack foods reported acrylamide concentration of dry roasted peanuts as in the range of 9-84 $\mu \mathrm{g} \mathrm{kg}^{-1}$ and average $42 \mu \mathrm{g} \mathrm{kg}^{-1}{ }^{[23]}$. Paola et al. reported that the acrylamide content of peanuts roasted at different temperatures between $1,08-42,86 \mu \mathrm{g} \mathrm{kg}^{-1}$ which is lower than the results of this study, since they used salted peanuts in shell ${ }^{[24]}$. Moreover a review of Bureau of Chemical Safety presented that acrylamide contamination of three different peanut butter as $122,99,85 \mathrm{\mu g} \mathrm{kg}^{-1}$ and of salted peanuts as $31 \mu \mathrm{g} \mathrm{kg}^{-1}{ }^{[20]}$. It is seen that salted peanuts have relatively lower acrylamide content, because salting process provide monovalent cations to prevent acrylamide formation like in study of Gökmen and Şenyuva ${ }^{[25]}$. Peanut butter showed relatively higher acrylamide concentrations than peanut kernels because of free fat content. It is thought that free fat content may promote acrylamide formation via acrolein pathway in peanut samples ${ }^{[20]}$.

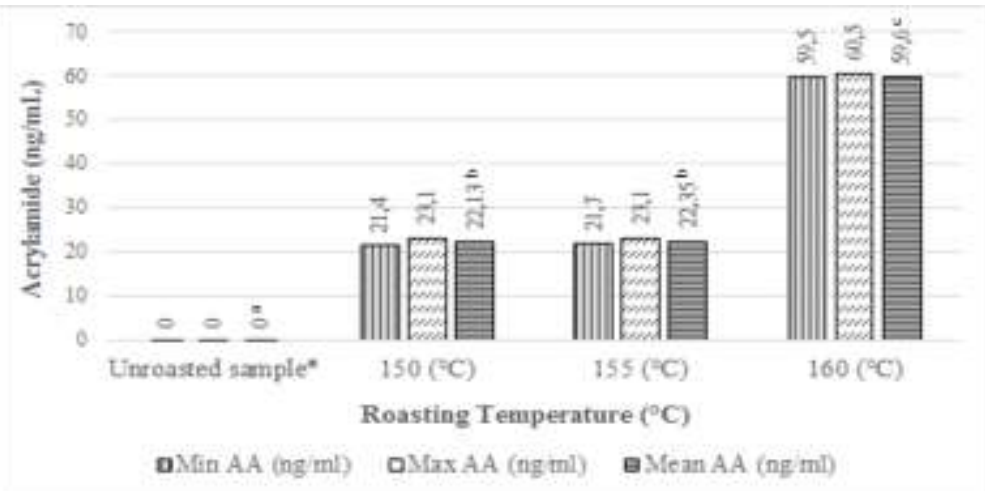

Figure 4. The minimum (Min), maximum (Max) and average (Mean) acrylamide (AA) concentrations of peanuts roasted at different temperatures $(\mathrm{n}=6)$

*Under the detection limit (LOD=0,33 $\mathrm{ng} \mathrm{mL}^{-1}$ )

a-d: The values with same letter are not significantly different for each parameters $(p>0.05)$ 


\section{Conclusion}

In this study the effect of roasting conditions (time-temperature) on acrylamide formation were investigated because of high preference of double roasted nut products by consumers. Usually consumers choose to eat nuts as a healty snack food because of beneficial components of them. Although when they prefer double roasted nuts, they are exposed to higher acrylamide contents. From this study, it is concluded that the maximum acrylamide contents were determined in the nuts roasted at highest temperatures. In order to minimize acrylamide content, it should be avoided from very high roasting temperatures. It is determined that there is no acrylamide formation in all unroasted nut samples, therefore some nuts especially almonds should be consumed without roasting in order to prevent hazardous health effect of acrylamide.

\section{Acknowledgements}

We thank Namık Kemal University Scientific Research Project Department (Project NKUBAP.00.24.YL.14.15) for financial support and NKU Central Research Laboratory (NABİLTEM) for LC-MS/MS analyses.

\section{References}

[1] L.W. Claeys, K.D. Vleeschouwer and M.E. Hendrckx, Quantifying the formation of carcinogens during food proccessing: acrylamide, Trends in Food Science \& Technology, 16, 2005, 181-193.

[2] E. Alpözen, İzmir gevreğinde akrilamid düzeylerinin belirlenmesi ve pişirme koşullarının akrilamid oluşumu üzerine etkileri, doctoral diss., Ege Üniversitesi Fen Bilimleri Enstitüsü, Gıda Mühendisliği Anabilim Dalı, İzmir, 2012

[3] IARC, Some industrial chemicals, Monographs on the Evaluation of Carcinogenic Risks to Humans, Lyon, France, 1994, 60: 389433.

[4] A. Karagöz, Akrilamid ve Gıdalarda Bulunuşu, TAF Preventive Medicine Bulletin, 8(2), 2009, 187-192.

[5] V. Gökmen, T.K. Palazoğlu and H.Z. Senyuva, Relation between the acrylamide formation and time-temperature history of surface and core regions of french fries, Journal of Food Engineering, 77, 2006, 972-976.

[6] Y. Zhang and Y. Zhang, Formation and reduction of acrylamide in Maillard reaction: a review based on the current state of knowledge, Critical Reviews in Food Science and Nutrion, 47 (5), 2007, 521-542.

[7] M. Taşan, Tahıl Kaynaklı Ürünlerde Akrilamid Varlığı, Türkiye 10. Glda Kongresi, Erzurum, 2008, 4: 395-398

[8] H. Ölmez, F. Tuncay, N. Özcan and S. Demirel, A survey of acrylamide in foods from the Turkish market, Journal of Food Consumption and Analysis, 21, 2008, 564-568.

[9] D.S. Mottram, B.L. Wedzicha and A.T. Dodson, Acrylamide is formed in the Maillard reaction, Nature, 419 (6906), 2002, 448-449.

[10] D. Taeymans, J. Wood, P. Ashby, I. Blank, A. Studer, R.H. Stadler, P. Gonde, P.V. Eijck, S. Lalljie, H. Lignert, M. Lindblom, R. Matissek, D. Müller, D. Tallmadge, J. O'Brien, S. Thampson, D. Silvani and T. Whitmore, A review of acrylamide: an industry, perspective on research, analysis, formation and control, Critical Reviews in Food Science and Nutrition 44 (5), 2004, 323-347.

[11] M. Taşan and B. Arslan, Akrilamid: kimyası, oluşum mekanizmaları ve gıdalarda bulunuşu, Hasad Gıda, 23 (268), 2007, 16-21.

[12] V. Gökmen and H.Z. Şenyuva, Effects of some cations on the formation of acrylamide and furfurals in glucose- asparagine model system, Eur Food Technol, 225, 2007, 815-820.

[13] Y. Xu, B. Cui, R. Ran, Y. Liu, H. Chen, G. Kai and J. Shi, Risk assessment, formation and mitigation of dietary acrylamide: current status and future prospects, Food and Chemical Toxicology, 69, 2014, 1-12.

[14] M.M. Ali Omar, A.A. Elbasir and O.J. Schmitz, Determination of acrylamide in Sudanese food by high performance liquid chromatography coupled with LTQ orbitrap mass spectrometry, Food Chemistry, 176, 2015, 342-349.

[15] M. Özdemir, F.G. Seyhan, A.K. Bakan, S. İlter, G. Özay and O. Devres, Analysis of internal browning of roasted hazelnuts, Food Chemistry, 73, 2001, 191-196.

[16] M. Jägerstad and K. Skog, Genotoxicity of heat-processed foods, Mutation Research, 574, 2005, 156-172.

[17] H. Lukac, T.M. Amrein, R. Perren, B. Conde-Petit, R. Amadó and F. Escher, Influence of roasting conditions on the acrylamide content and the colour of roasted almonds, Journal of Food Science, 72:1, 2007, 33-39.

[18] S.E. Kepekci-Tekkeli, C. Önal and A. Önal, A review of current methods for the determination of acrylamide in food products, Food Analytical Methods, 5:1, 2012, 29-39.

[19] M. Friedman, Chemistry, biochemistry and safety of acrylamide: A review, Journal of Agricultural and Food Chemistry, 51, 2003, 4504-4526.

[20] Health products of food branch, Bureau of Chemical Safety, Health Canada's revised exposure assessment of acrylamide in food, August 2012

[21] T.M. Amrein, L. Andres, B. Schönbächler, B. Conde-Petit, F. Escher and R. Amadò, Acrylamide in almond products, Eur Food Res Technol, 221, 2005, 14-18.

[22] V. Gökmen and H.Z. Şenyuva, Study of colour and acrylamide formation in coffee, wheat flour and potato chips during heating, Food Chemistry, 99, 2006, 238-243.

[23] P. Cressey, B. Thomson, M. Ashworth, P. Grounds and E. McGill, Acrylamide in New Zealand food and updated exposure assessment, Ministry of Agriculture and Forestry (MAF), Bureau Wellington, 2012

[24] E. L. De Paola, G. Montevecchi, F. Masino, D. Garbini, M. Barbanera and A. Antonelli, Determination of acrylamide in dried fruits and adible seeds using QuEChERS extraction and LC seperation with MS detection, Food Chemistry, 217, 2017, 191-195.

[25] V. Gökmen and H.Z. Senyuva, Acrylamide formation is prevented by divalent cations during the Maillard reaction, Food Chemistry $103,2007,196-203$. 